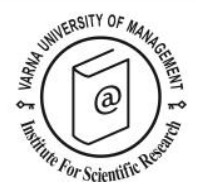

\title{
Food tourism and regional development: A systematic literature review
}

\author{
Susana Rachão ${ }^{1 *}$, Zélia Breda ${ }^{2}$, Carlos Fernandes $^{3}$ and Veronique Joukes ${ }^{4}$
}

Received: 09/07/2018 Accepted: 20/09/2018

\footnotetext{
${ }_{1} \mathrm{PhD}$ Candidate, Department of Economics, Management, Industrial Engineering and Tourism, University of Aveiro, Portugal, e-mail: susanarachao@ua.pt, phone: +351966533419

2 Department of Economics, Management, Industrial Engineering and Tourism, and Research Unit 'Governance, Competitiveness and Public Policies', University of Aveiro, Portugal

${ }^{3}$ School of Technology and Management, Polytechnic of Viana do Castelo, Portugal

${ }^{4}$ Department of Economics, Sociology and Management, School of Human and Social Sciences, University of Trás-os-Montes and Alto Douro, Portugal

* Corresponding author
}

\begin{abstract}
Using food as a differentiating asset of destinations and its potential in influencing tourists' travel decisions is being much discussed in academia. Different countries use distinct terms to relate food to tourism. Concepts such as culinary tourism, food tourism and gastronomy tourism are used interchangeably. This paper aims to explore regional innovation strategies based on food and tourism and on how they can contribute to destination management. The study adopts a systematic literature review by focusing on two main databases, namely SCOPUS and ISI Web of Science. In total, 538 articles (from 1985 to 2017) published in English peer-reviewed academic journals were analysed. The systematic review revealed that food and tourism has been approached from varied perspectives, from interactions with traditional protection strategies under European food quality labels, such as Protected Designation of Origin (PDO) and the Protected Geographical Indication (PGI), to innovative actions, which encapsulate the reengineering of places transforming them into creative food spaces or food clusters. Finally, this paper seeks to contribute to the body of knowledge on food and tourism, under the perspective of regional innovation strategies, applying a qualitative systematic literature review of a 27 selected articles within the scope of the research.
\end{abstract}

(C) 2019 Varna University of Management. All rights reserved

Keywords: food, tourism, regional development, policies, systematic literature review

Citation: Rachão, S., Z. Breda, C. Fernandes and V. Joukes (2019) Food tourism and regional development: A systematic literature review. European Journal of Tourism Research 21, pp. 33-49

\section{Introduction}

The role of food tourism in territorial dynamics has become an important issue for local and/or regional development. However, it is still an understudied topic, deserving further research, certainly if ever more new establishments associating food and tourism - creative food spaces and food clusters - appear (Burnett, 
Food tourism and regional development: a systematic literature review.

2014; Cavicchi \& Stancova, 2016; Everett \& Aitchison, 2008; Richards, 2015).

Initial research showed different concepts being used interchangeably to associate food to tourism. Culinary tourism appears mostly in North American publications, food tourism in Australia and New Zealand and gastronomy tourism in Europe. It is not the scope of this paper to review these concepts in-depth. As such, food tourism is the terminology applied throughout this paper, the reason being justified later in this paper.

Already a decade ago, Everett \& Aitchison (2008) claimed that there was a scarcity of academic research when it comes to tourists engaging with local food and, hence, its impact in regional development and sustainability in an interdisciplinary approach. In fact, one of the first efforts to evaluate the impact of food in territorial dynamics was made by the European Commission establishing the interconnection between food, gastronomy and territory, stressing their potential for innovating and diversifying regional strategies, particularly when it comes to developing regional umbrella brands for European Union sustainable agrofood products (Cavicchi \& Stancova, 2016). Immediately after, the World Tourism Organization (UNWTO) reiterated the tourism perspective, stating that local cultures can be absorbed through food/gastronomy and wine tourism since they have become one of the most dynamic and creative parts of tourism (UNWTO, 2017). Furthermore, the United Nations Educational, Scientific and Cultural Organization (UNESCO) and Organisation for Economic Co-operation and Development (OECD) associated gastronomy to the creative industries, based on the relationship between culture and food (Kivela \& Crotts, 2006) allowing visitors to access culture and heritage in an innovative way by adding creative elements (OECD, 2014). It is further suggested that food is one of the essential expressions of any culture and one of the elements of creativity in everyday life that is engaging for many tourists (Richards, 2012) and the creative elements are added by the combination of knowledge, skills and values through different food elements and/or places outside traditional eating establishments (Justiniano, Jaría-
Chacón \& Valls-Pasola, 2017). Additionally, the UNWTO (2016, p. 15) claims that " $88.2 \%$ of destinations consider gastronomy a strategic element in defining its image and brand". This trend is confirmed by the increasing number of existing publications that analyse food tourism from a marketing perspective.

The United Nations Conference on Trade and Development (UNCTAD), on the other hand, does not directly recognise the gastronomy sector as a creative industry, but considers it under the umbrella of cultural heritage, along with crafts, traditional cultural expressions, festivals and cultural sites (UNCTAD, 2008). In this line of thought, namely highlighting the relevance of events as trading spaces in stimulating economic, cultural, environmental and social cohesion (Getz, 2009), wine and gastronomy festivals, wine museums and art exhibitions in wineries can be characterised as examples of creative activities and adequate to integrate UNESCO'S Framework for Cultural Statistics (UNESCO-UIS, 2009).

As the central focus of this study is the identification of regional innovation strategies based on food tourism, the most representative studies addressing both food tourism and territorial (urban and rural areas, regions, and destinations) dimensions were reviewed according to a set of established criteria that is explained in the methodology. This paper also provides a theoretical background on concepts related to food, tourism and territorial innovation strategies, the main research results and concluding remarks, and provides a discussion on the research limitations and pathways for future research.

\section{Literature review}

\section{Food tourism}

In the realm of tourism studies, some academic publications have highlighted the importance of relating food and tourism in managing destinations from both demand and supply sides. Some of these publications discuss that food experiences can add value to tourism (Hall et al., 2003; Hjalager \& Richards, 2002), since food is a key aspect of the travel experience and essential to understand the culture of the place visited (Getz, Robinson, Andersson, \& Vujicic, 2014). Such debates led 
to new critical discussions regarding the complex food tourism system in a post-modern food experience economy (Stanley \& Stanley, 2015; Yeoman, McMahon-Beattie, Fields, Albrecht, \& Meethan, 2015).

Food tourism is the terminology applied throughout this paper. It follows the example of the Ontario Culinary Tourism Alliance (OCTA) as well as the World Food Travel Association (WFTA), who switched from culinary tourism to using food tourism as it is more encompassing of the offerings (e.g. farms, artisanal producers), while the culinary term "can sometimes have an exclusive or elitist ring to it" (WFTA, 2018, p. 7). The UNWTO adopted the most used definition of food tourism, as proposed by Hall \& Mitchell (2001). Table 1 displays what should be understood under "food tourism".

It is suggested that food not only satisfies physical needs but also provides opportunities to enhance social relationships, learning and belonging (Hjalager \& Johansen, 2013; Hjalager \& Wahlberg, 2014). Moreover, food consumption spaces, as bistro bars or coffeehouses, have become "areas of culture performance, rather than simply areas of physical consumption" (Kim \& Ellis, 2015, p. 154) and as a means of exchanging life experiences and socializing with local culture (Mitchell \& Hall, 2003; OCTA \& Skift, 2015; UNWTO, 2012).

"In recent years gastronomy has become an indispensable element in order to get to know the culture and lifestyle of a territory" (UNWTO, 2012 , p. 10). The demand for new food products with local origins is, for example, amplified by Michelin star chefs (Hjalager \& Wahlberg, 2014), who play the role of "interpreters of the territory" (UNWTO, 2012, p. 15). For destinations, food consumption represents a substantial proportion of tourist spending (Eurostat, 2015).

Broadway (2017, p. 470) suggests that "food

Table 1. Food tourism terminologies

\begin{tabular}{|c|c|}
\hline Author(s) & Terminology \\
\hline Long (1998, p. 21) & "The intentional, exploratory participation in the foodways of an Other". \\
\hline $\begin{array}{l}\text { Hall \& Mitchell (2001, p. } \\
\text { 308); UNWTO (2012) }\end{array}$ & $\begin{array}{l}\text { "Visitation to primary and secondary food producers, food festivals, } \\
\text { restaurants and specific locations for which food tasting and/or } \\
\text { experiencing the attributes of specialist food production region are the } \\
\text { primary motivating factor for travel". }\end{array}$ \\
\hline OCTA \& Skift $(2015$, p. 4$)$ & $\begin{array}{l}\text { "Food tourism is any tourism experience in which one learns about, } \\
\text { appreciates, and/or consumes food and drink that reflects the local, } \\
\text { regional or national cuisine, heritage and culture". }\end{array}$ \\
\hline WFTA $(2018$, p. 7) & $\begin{array}{l}\text { "Food tourism is the pursuit and enjoyment of unique and memorable food } \\
\text { and drink experiences, both far and near". }\end{array}$ \\
\hline
\end{tabular}

Source: own construction

\section{Levels of involvement}

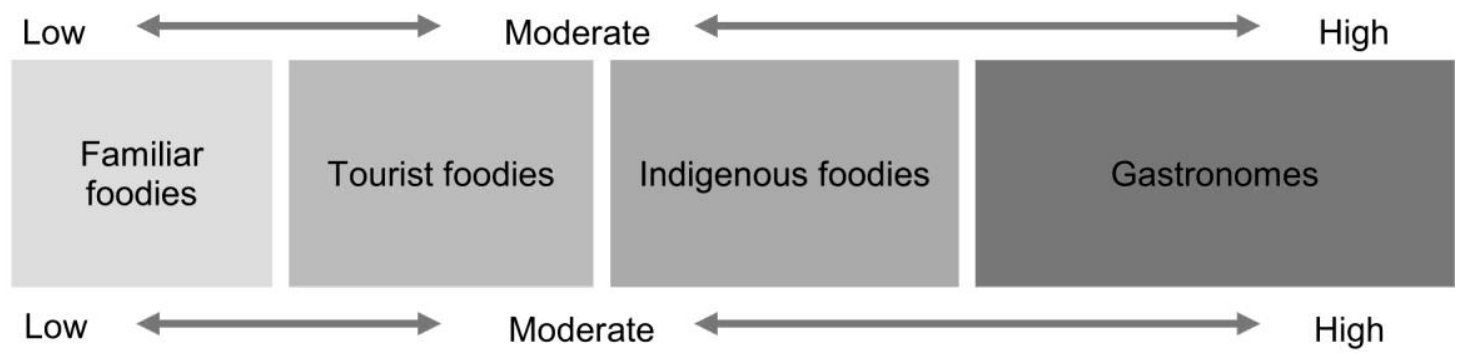

Levels of interest

Source: Adapted from Mitchell \& Hall (2003)

Figure 1. Levels of involvement and interest among food consumer 
tourism's growth is part of an overall rise in special interest tourism" that results from socioeconomic development and living standard improvement of recent decades" (Metaxas \& Karagiannis, 2016, p. 3). This assertion follows Mitchell \& Hall (2003) who identified market segmentation based on the level of interest and involvement of visitors in local food and cuisine at destinations, as illustrated in Figure 1. The origin and cultural distance of the consumer (international or domestic visitors) creates different positions regarding food (Prada-Trigo, 2017), thus different levels of involvement.

As illustrated in Figure 1, the higher the level of involvement, the higher the level of interest is. "Gastronomes" is how these most involved and interested consumers are called. When it comes to "indigenous foodies" they show moderate to high levels of involvement/interest. "Tourist foodies" and "familiar foodies" display low to moderate levels of involvement/interest.

The levels of involvement can also be explained by the rise of postmodern consumption (Richards, 2014), portrayed by changes of eating styles along with the trend towards increased consumption of typical food products, both reflecting the search for meaning of modern cultural consumers. These contemporary food consumption tendencies are impacting the territorial organization, and, therefore, the management of tourism destinations. As a result, products with strong territorial attachment are viewed as potential micro-attractors in contemporary tourism demand, in which authenticity, local traditions and tacit knowledge are pre-conditions for selfdevelopment (in intellectual and leisure ways). "The interest of visitors in food tourism is growing together with interest in culture, traditions, emotions, experiences and creativity" (Kiralova \& Hamarneh, 2017, p. 18).

Food tourism also entails drink experiences (see Table 1 - OCTA \& Skift and WFTA terminologies), particularly wine-related events, visitation to wineries and vineyards but also beer festivals and whiskey routes. Wine tourism considered as a subcategory of food tourism (OECD, 2012), is an important marker of territories and a crucial input for the tourism industry. In most regions of the world, wine tourism is just one element of the total tourism offer, yet in some regions, for example in Australia and France, it gets privileged attention as it is the main tourism product to attract visitors to the destination. Regardless of wine tourism being included in food tourism, it can be seen as a category by itself (Charters \& Ali-Knight, 2001; Getz, 2000), due to its capability of generating economic benefits to an array of local stakeholders and its complementarity with other service sectors as hospitality, arts and entertainment (Carlsen \& Charters, 2006).

\section{Territorial innovation strategies}

Since the early 1970's, spatial relations within advanced capitalist economies have been radically restructured, due in part to the decline of old industries and the growth of the service sector (Meethan, 1996). Immediately after the 1973 oil crisis, governments worldwide began to reassess their economic development strategies, starting to focus more on local and regional political approaches based on endogenous resources (Moulaert \& Sekia, 2003). In fact, innovation and knowledge creation set new challenges both for policy makers and for governance models, as they have to find new ways to integrate strongly increasing numbers of new forms of businesses influenced by modern consumer lifestyles (Cavicchi \& Stancova, 2016).

Researchers have discussed different knowledge and innovation models to promote territorial dynamics, such as regional innovation systems, territorial innovation systems and territorial innovation models (Cooke, 2008; Moulaert \& Mehmood, 2010; Moulaert \& Sekia, 2003). In general, the different models share a similar goal - the strategical development of "organisational proximity" - which has been improved through the globalization and digitalization of the world.

The search for innovative products and experiences is reflected by the new spatial configurations of tourism places (urban and rural). The innovation construct is comprised of several categories and can be applied at different stages of development of a tourism product. Hjalager (2010) identifies five categories of innovation (Table 2). 
The increase of food tourism reflects the improvement of the economic living standard of postmodern consumption societies. Nevertheless, the postmodern societies, influenced by the effects of globalisation in which culture, fashion and eating styles are patterned have led to a search for authenticity and, therefore the development of territorial valorisation strategies.

Along with the rise of the service sector, investing in a "cultural economy" has been an outstanding characteristic of the capitalist societies (Perkins et al., 2015; Scott, 2010). As a result we have witnessed the appearance of cultural and creative districts, in general, and enogastronomic clusters, in particular. New stakeholders are increasingly involved and looking forward to develop cross-sectoral and transregional collaborations in order to generate innovative agro-food products and services (Cavicchi \& Stancova, 2016).

Yet when it comes to the tourism industry, for a long period of time production sites and consumption spaces were often discussed as separate units in tourism discourses overlooking the 'in-betweeness' of the categories (Everett, 2012). But new spatial configurations of tourism places, such as typical production sites, i.e. bakeries, dairy factories and olive oil industrial units are being turned into creative enogastronomic food systems, and a means to know the local lifestyle. These enogastronomic food systems are seen as innovative territorial strategies.

Thus, there is an overall need for a better understanding of the benefits of integrating food tourism strategies in a broader territorial development and destination management context.

\section{Methodology}

Data extraction, search strategy and inclusion criteria

This research addresses the following review question:

How can food related to tourism contribute to regional innovation strategies in destination management?

In order to identify scientific contributions in the research area, both empirical and conceptual, the present study adopted a systematic literature review (SLR) approach. A SLR employs a specific methodology in order to limit bias, but "will not completely eliminate it" (Pickering \& Byrne, 2014, p. 546), producing a scientific summary of the evidence collected in one or more academic domains such as, business and management, arts and humanities among others (Petticrew \& Roberts, 2006). As a result, a SLR can provide the most relevant information in the research field as it assists the researcher to prioritize and organize the data to be analysed (Sedarati, Santos, \& Pintassilgo, 2018). A SLR should provide comprehensive, objective and replicable data which can be analysed (Weed, 2006). Despite

Table 2. Categories of innovation

\begin{tabular}{|c|c|c|}
\hline $\begin{array}{l}\text { (1) Product } \\
\text { or service }\end{array}$ & $\begin{array}{l}\text { Changes directly observed by the customer and } \\
\text { regarded as new; new to the particular enterprise or } \\
\text { destination. }\end{array}$ & E.g. mobile phone check-in. \\
\hline (2) Process & $\begin{array}{l}\text { Typically backstage initiatives, which aim at escalating } \\
\text { efficiency, productivity and flow (e.g., technology } \\
\text { investments, reengineered layouts for manual work } \\
\text { operations). }\end{array}$ & order \\
\hline $\begin{array}{l}\text { (3) } \\
\text { Man }\end{array}$ & $\begin{array}{l}\text { f organising internal collaboration, directing } \\
\text { ering staff, building careers with pay and }\end{array}$ & $\begin{array}{l}\text { E.g. } \\
\text { mee }\end{array}$ \\
\hline $\begin{array}{l}(4) \\
\text { Management }\end{array}$ & ment of customers or redirect existing & E \\
\hline $\begin{array}{l}(5) \\
\text { Institu }\end{array}$ & $\begin{array}{l}\text { w collaborative/organisational structure or legal } \\
\text { mework that redirects or enhances the business in } \\
\text { tain fields of tourism. }\end{array}$ & $\begin{array}{l}\text { E.g. horizontal links between } \\
\text { hospitality and entertainment } \\
\text { agencies. }\end{array}$ \\
\hline
\end{tabular}

Source: own construction based on Hialaqer (2010) 
the increasing number of tourism research publications in this specific area over the last two years (2017 and 2018) (Elsevier, 2018b), this technique is still not widely used in the tourism academic field (Carter et al., 2015).

A set of criteria was established in order to select pertinent publications (conference papers, articles, review articles, articles in press or research notes) in peer-reviewed journals: (i) being indexed in the electronic search database SCOPUS and ISI Web of Science before November 2017; (ii) approaching food and tourism in the context of territory, innovation and networks; (iii) being written in English.

More specifically, a combination of keywords were used to collect data, specifically: "culinary tourism", "food tourism", "food-related tourism", "gastronomic tourism" and "gastronomy tourism" in the fields "abstract", "keywords" and "title", as well as in the subject areas "Arts \& Humanities", "Business, Management and Accounting", "Economics, Econometrics and Finance" and "Social Sciences" as shown in Figure 2Грешка! Източникът на препратката не е намерен..

Despite the complementarity of gastronomy and wines as tourism products, each product has distinct dynamics and supporting structures. The wine tourism ecosystem encapsulates primary resources (e.g. vineyards, wine production processes, wineries) and is considered as a sub-set of

\section{Searched keywords}

"Culinary tourism"; "food tourism"; "food-related tourism"; "gastronomic tourism" and "gastronomy tourism"

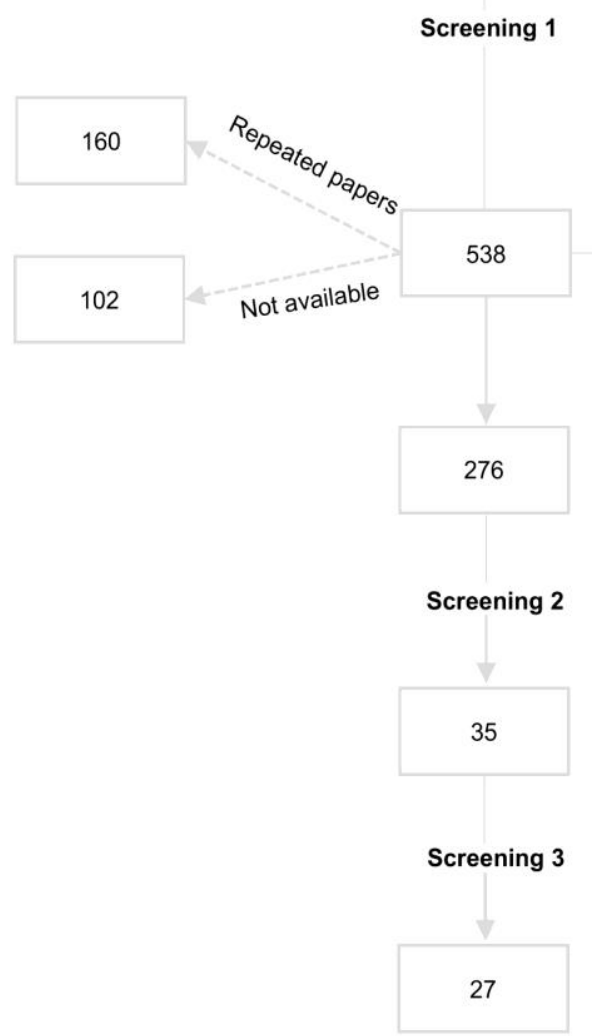

Criterion 1

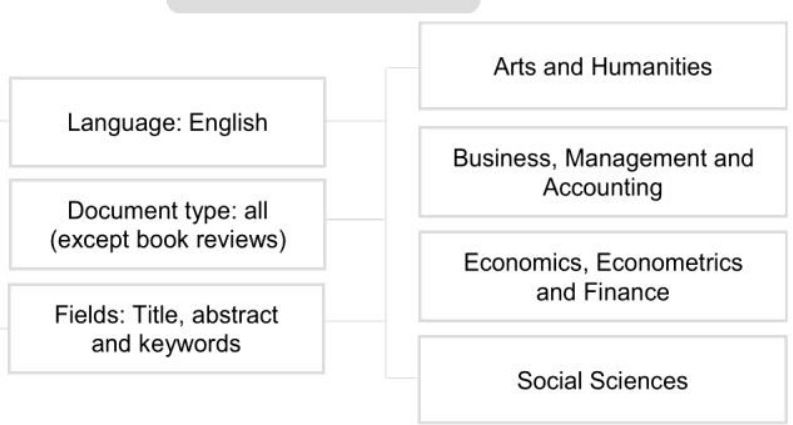

Criterion 2

Paper refers to territory, innovation and

local food networks within food tourism (abstract reading and analysis)

Figure 2. Flowchart describing the phases of the selection of relevant papers for the systematic review 
food tourism (Hall, 1996); differing from food tourism regarding policies and planning. For this reason, and as wine tourism is previously described as an economic, territorial and social robust activity, the authors have focused mainly on the importance of the food tourism phenomenon in destination management emphasizing territorial innovation strategies.

Different "overall" concepts are used in different regions: "Food tourism" in Australia/New Zealand, "culinary tourism" in United States of America/Canada and "gastronomy tourism" in Europe. For this study's purpose the term food tourism was adopted to develop the analysis, since it has a larger bibliographic scope than the other.

Scopus was selected since it is the broadest bibliographical database, containing summaries and academic citations of scientific literature subject to peer review (Elsevier, 2018a). Additionally, the ISI Web of Science was chosen in order to ensure comprehensiveness, as it is the first citation database set of references compiled by the Institute of Scientific Information (Web of Science Clarivate, 2018). Book chapters and book reviews were excluded since, usually, they are not available in a free basis in the selected electronic databases, and sometimes are not peer reviewed.

In order to reach the greatest possible number of publications, whenever these were not accessible through the selected databases, academic social networks, such as ResearchGate and Academia.edu, were used to contact the authors and request the fullpaper. Every time an article was somehow updated or duplicated, only the initial publication was analysed.

538 papers were extracted to an Excel spreadsheet in order to organize and detect duplicates. An initial screening led to 276 unique papers being identified. The second stage involved the abstract reading and analysis in order to verify if they were related to the topics "territory", "innovation" and "local food networks", which narrowed down the results to a total of 35 papers. A third screening was performed based on a criterion in which journals should be listed in the SCImago Journal and Country Rank (SJR). SJR ranking uses citation data from Scopus and measures the influence of a given journal by the number of citations received that are weighted depending on the subject field and the journal's prestige (SCImago Journal \& Country Rank, 2018). As a result, 8 papers were excluded, as they are not included in the ranking, resulting in 27 papers identified as eligible for analysis. Once the sample of 27 papers was settled, different analyses were done. Figure 3 represents the chronological distribution of the publication years of the articles.

\section{Systematic literature review results}

This section frames the descriptive results of the systematic literature review about the role of food tourism within territorial innovation strategies since 2008.

A qualitative strategy approach based on the content analysis of the 27 scientific papers was undertaken. A deductive approach (theorydriven) was applied in order to gain new and deeper understanding of the phenomenon (Altinay \& Paraskevas, 2008).

After reading the full papers, they were divided by rural and/or urban focus and four separate groups of studies regarding their approach were identified. A first group totalizing fourteen papers emphasises the role of food tourism in regenerating rural areas, a second group encompassing eight papers has an explicit urban focus, a third group does not specify this kind of focus and entails three papers, and the fourth group uses a mixed rural and urban focus enclosing two papers.

Until 2008 the survey did not reveal any published articles. The first paper relating food, tourism and territorial identity was published in 2008 in the Journal of Sustainable Tourism, with the title "The role of food tourism in sustaining regional identity: A case study of Cornwall, South West England". The number of publications on food tourism and territorial innovation increased at a very slow pace until 2016, when seven papers were published in distinct scientific journals (Figure 3 ). 
Food tourism and regional development: a systematic literature review.

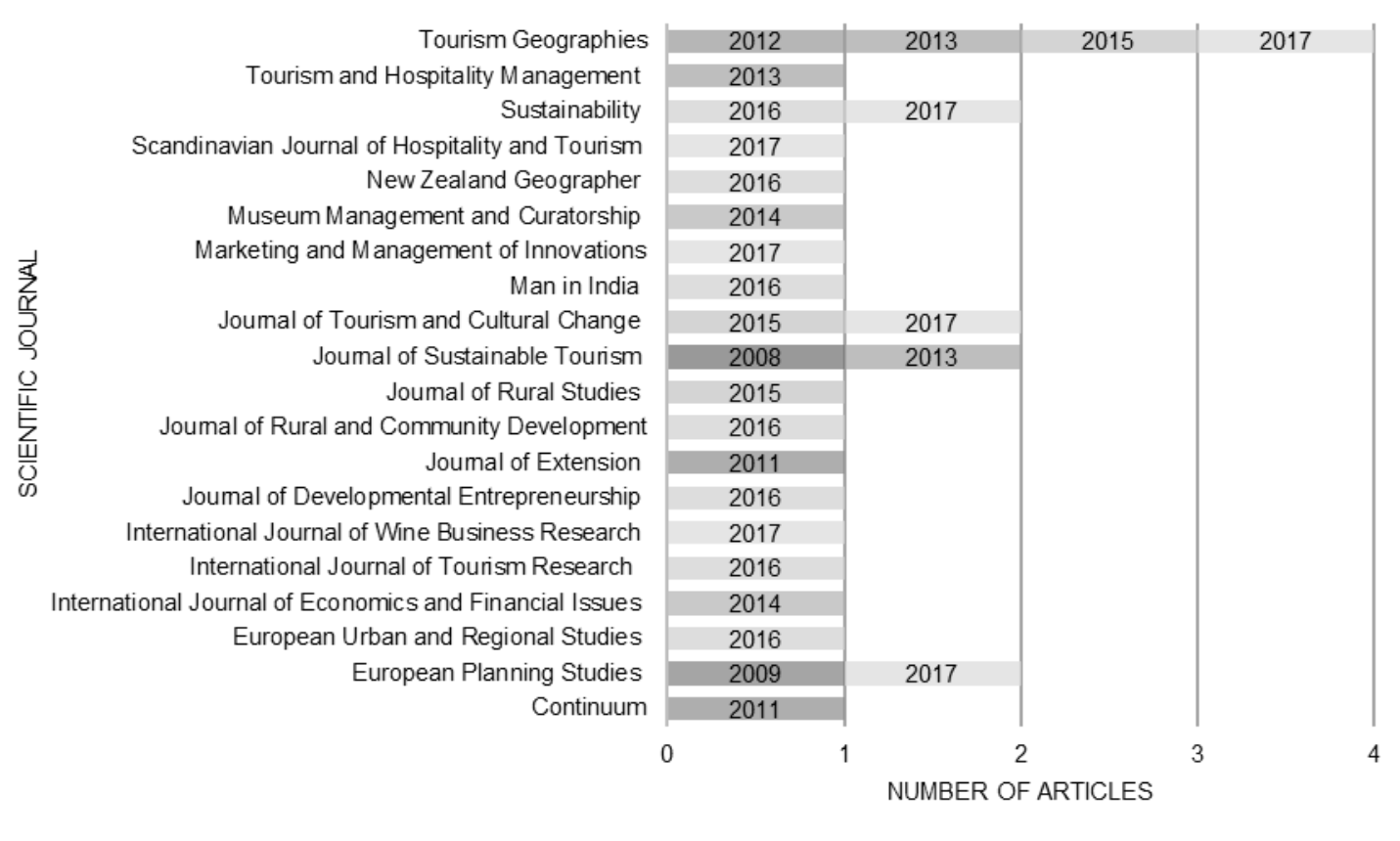

Figure 3. Distribution of the sample per year of publication and per scientific journal

In 2017, an additional seven papers were published, meaning that over half of the sample was published. Thus between 2016 and 2017 the majority of the papers used for this study was published. The journal with the most publications is Tourism Geographies (Figure ). Everett (2008; 2012), Hjalager (2013; 2014) and Lee et al. $(2015 ; 2016)$ were the authors with the highest number of publications (with two articles each).

Table 3 summarises the main authors per subject of investigation/dimension. Considering the inclusion criterion number 2 ("paper refers to territory, innovation and local food networks within food tourism"), data evidence that innovation, territorial networks, followed by governance and place development were the most discussed dimensions. Especially Denmark, United States of America and Italy were studied under the dimensions of innovation as well as of territorial networks. Particular attention was paid to the governance dimension in three of the twenty-seven studies analysed with fieldwork conducted in Italy, Spain, Indonesia and Ireland.
Table 4 details the different research methodologies employed in the twenty-seven studies under analysis. Of these, seven are theoretically-based approaches in territorial strategies within agro-food-tourism systems focusing mainly on the supply-side and the remaining twenty have an empirical approach and are mostly supply-side-based. This evidence might be explained by the fact that territorial innovation strategies are seen mainly from the policy and governance points of view, since the government is the territorial manager (Hjalager, 2010).

Multiple data sources were frequently employed to evaluate the relationship between food tourism and territorial innovation strategies. Nineteen papers are predominantly qualitative in nature, applying interviews (semistructured, structured and in-depth), focus group, observation (participant and nonparticipant) and content analysis of documents as data collection techniques. Respecting secondary data, the main sources were national or regional tourism plans, governmental policies, technical reports and media sources. 


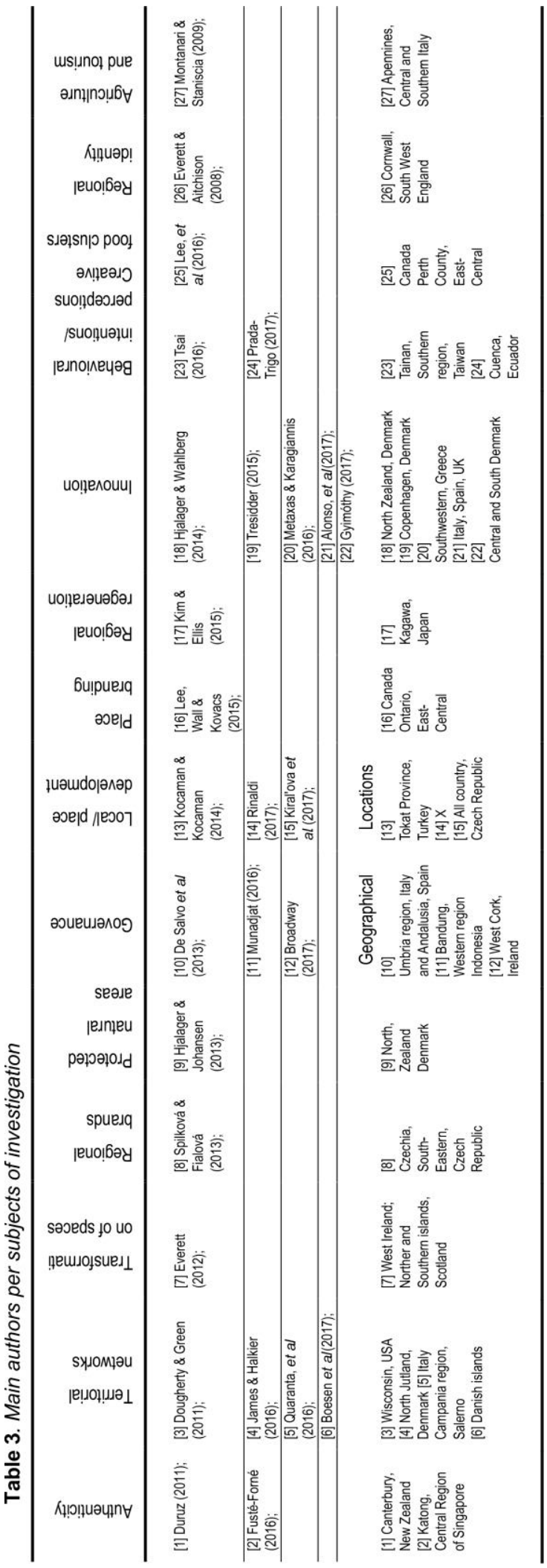

Only three studies are quantitative in nature and all used questionnaires: Tsai (2016) applied structural equation modelling in order to model behavioural intentions in consuming local food; Prada-Trigo (2017) employed the Mann-Whitney test to evaluate the perception of residents and visitors to a territorial product, and Kiralova \& Hamarneh (2017) used the arithmetic mean and sample coefficient of variations to assess local gastronomy as a tool of food tourism development.

Table 4 shows that the samples under study were mainly composed by restaurateurs, farmers, food producers, representatives of local authorities, tourism stakeholders and domestic/ international tourists. The wide range of participants in the samples reflects the need for a comprehensive understanding of the tourism industry. Ranging from private to public and third sectors, destination managers should evaluate and plan the operations within the tourism supply chain in order to fulfil simultaneously tourists' needs on the one hand and business goals of different firms on the other hand.

\section{Food tourism and its position in territorial innovation strategies}

Recognising the potential of food as a factor of regional development, the European Union established in 1992 two legal instruments aiming the protection of regional food, namely the Protected Designation of Origin (PDO) and the Protected Geographical Indication (PGI) (European Commission, 2013). These legal instruments were implemented in order to respect specific traditions and to attest the quality of food since the progressive industrialisation of the food production resulting from the globalisation "has contributed to the re-territorialisation of food" (Montanari \& Staniscia, 2009, p. 1466).

They also "have a strong association with the regional development, since a great majority of PDO and PGI products come from the Less Favoured Areas" (Spilková \& Fialová, 2013, p. 180). Furthermore, they comprise food, place and tacit knowledge involved in the process of creation of typical products, therefore representing the site's history (Rinaldi, 2017), "embedded in a conservationist ideology, using 
Food tourism and regional development: a systematic literature review.
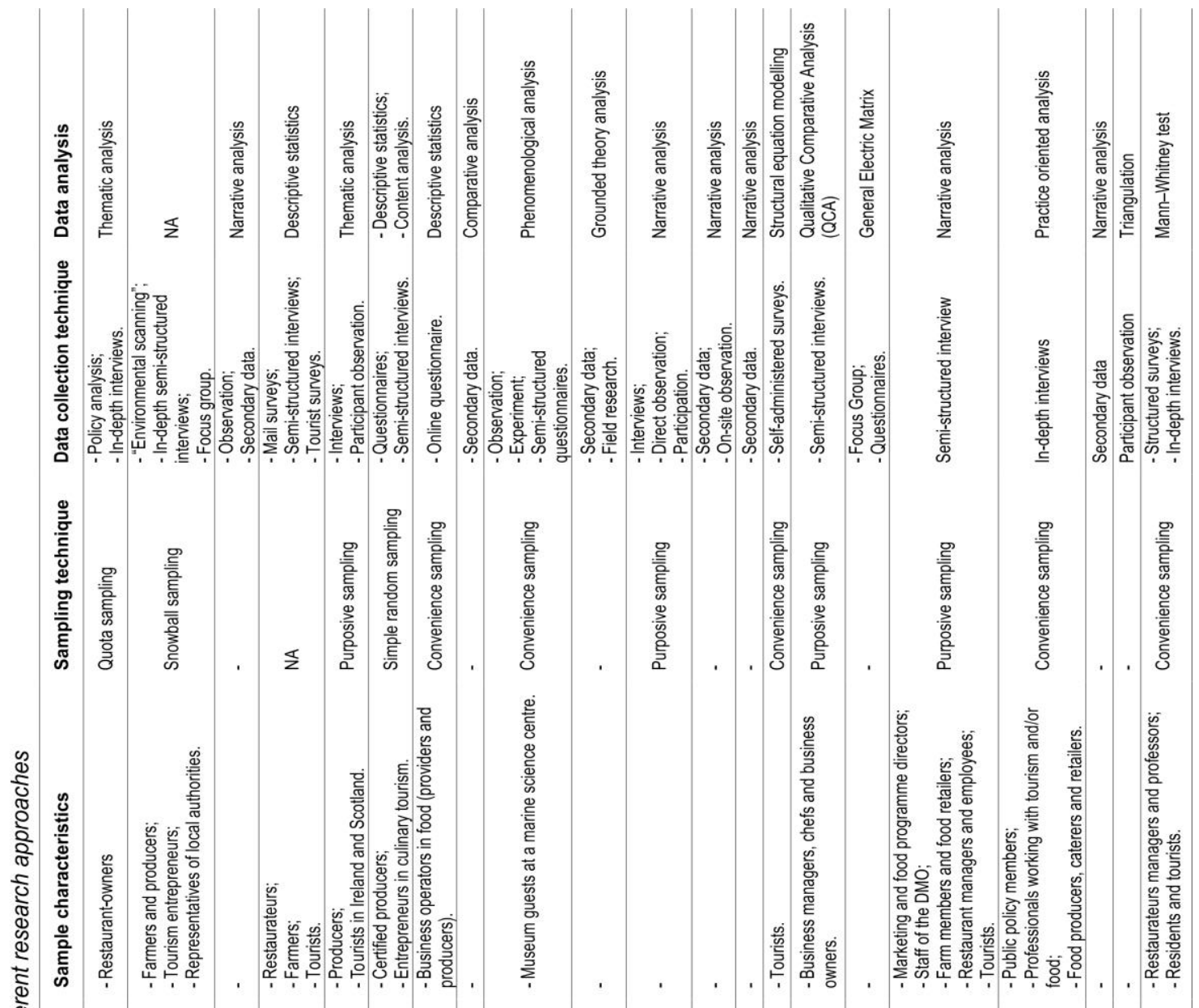

弯

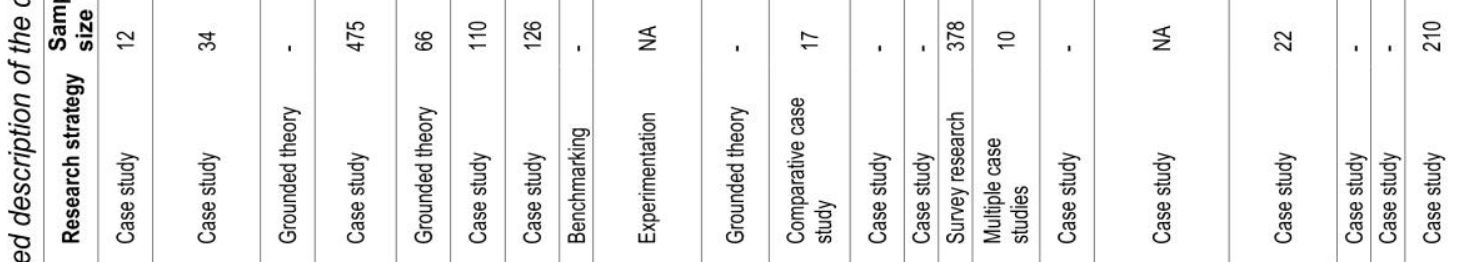

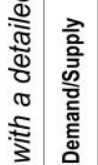

兽

密

के

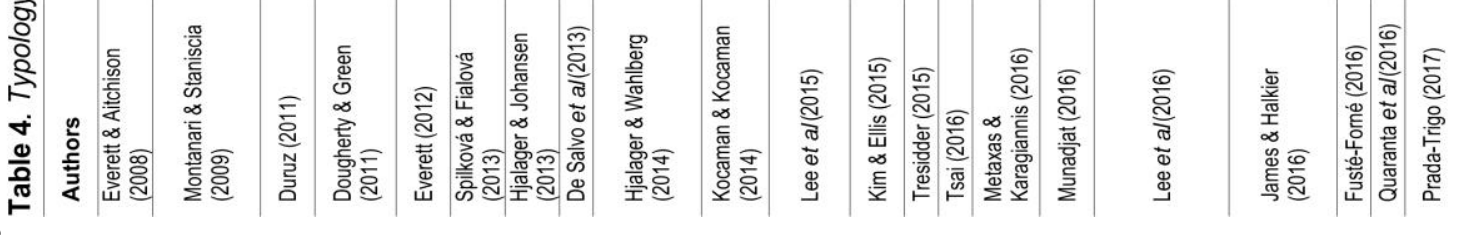




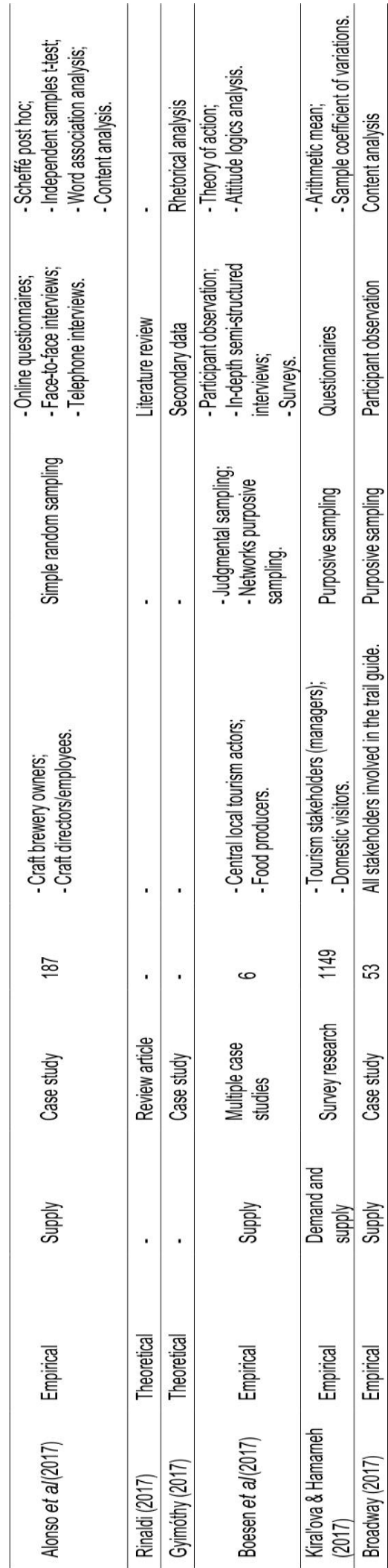

cultural-historical as well as geographical qualifiers of typicality" (Gyimóthy, 2017, p. 1204). "Typicalness, in fact, does not only depend on the productive process one takes to get the product done, but as well on the relations between the actors of the territorial system who give the product a collective dimension" (Salvo, Hernández-Mogollón, Di Clemente, \& Calzati, 2013, p. 24).

Products with "geographical indication" are attached to the place, the terroir, encompassing unique attributes that allow their identification (Rinaldi, 2017), giving a sense of place (Lee et al., 2015) and adding ethnographic and landscape values to gastronomic offerings (UNWTO, 2012). As such, food is a mixture of old and new with clear continuity with the past. The word tradition simply means long-established or handed down (Kim \& Ellis, 2015, p. 164).

Using innovation in order to safeguard traditional and local products and transform a typical dining experience into a tourist attraction is exemplified through the creation of "terroir restaurants". "The terroir restaurant may locate itself as both a response to and a refuge from globalization" (Tresidder, 2015, p. 350). The same argument could be made for the slow food movement (originated in Italy) in which local food producers have been encouraged by the government to preserve and promote local food production (OECD, 2012).

From a tourism perspective, according to James \& Halkier (2014), policymakers have tried to connect food and tourism, fundamentally through destination branding, providing new food tourism experiences and pushing supermarkets and restaurants in supplying local food products.

The link between food, territory and tourism is also developed by Tsai (2016) who stresses the importance of tourists' experiencing local cuisines in order to create a stronger attachment to destinations. In destination management, food tourism development is seen as an economic opportunity to improve, particularly, small and medium food and beverage enterprises (Munadjat, 2016). Yet, despite public sector efforts to promote local 
Food tourism and regional development: a systematic literature review.

products and dishes, local suppliers as restaurants still do not include the origin of their products in their menus (Broadway, 2017).

\section{Food clusters: a rural perspective}

"Very little is known about how local food systems" (Prada-Trigo, 2017) or "food clusters" (Lee et al., 2016, p. 73) are formed or how they operate. Indeed, "in some localities - e.g. Tuscany - food tourism is well-established, but in most European regions cross-sectoral relations are either limited or not systematically exploited" (Therkelsen \& Blichfeldt, 2012, cited in James \& Halkier, 2014, p. 8). As stated by Lee et al (2016) not all geographical places hold appropriate factor conditions to form a food cluster in which partnerships between public and private sectors along with a strong leadership are facilitators for the development of a food cluster. The lack of centralised ordering and delivery services for local food is one of the most significant barriers to develop local food tourism networks (Dougherty \& Green, 2011). Also, the level of trust among rural stakeholders is a challenging determinant for the success of an agro-tourism network where friendship "can prove more valuable than its economic benefits" (Quaranta, Citro, \& Salvia, 2016, p. 3) and poor awareness of local resources (e.g. services and activities) "hides a lack of trust between local actors" (p. 7).

The use of "Short Food Supply Chains" and "Alternative Food Networks", as advanced by Rinaldi (2017), can contribute to the improvement of local/regional food clusters. Producers can explore more ways to diversify their production (Fusté-Forné, 2016), promoting at the same time local agricultural products to domestic and international visitors. These alternative food networks also allow consumers to have a closer interaction with local producers. For tourism consumption experiences the same rule applies: the tourists have to be reconnected to the producer through the personalization of the selling channel (Everett \& Aitchison, 2008; Rinaldi, 2017).

When it comes to developing creative tourism experiences, food clusters have the ability to "offer visitors an array of culinary tourism opportunities, such as food tours and farm visits, as well as complementary experiences, such as arts-related activities" (Lee et al., 2015, p. 133). This association between local food and innovation can boost entrepreneurial businesses in food tourism consumption (Metaxas \& Karagiannis, 2016). Nevertheless, emphasizing the collaboration among agricultural producers, cultural heritage assets and creative industries, Lee et al., (2015) and Lee et al., (2016) have described the barriers and benefits of developing rural creative culinary places through food clusters. For instance, the authors acknowledge in their research that an industry-oriented approach acquires more funding from the local government and higher partnerships when comparing to a community-based approach.

From the demand viewpoint, visitors may spend more money during their stay (Lee et al., 2015), and demand ever more innovative onfarm food programs, allowing them to explore a destination in alternative ways (Dougherty \& Green, 2011). These alternative ways, which can be operationalized e.g. through food routes/trails (wine, olive, beer), are seen as tools for economic revitalization (Duruz, 2011; Everett, 2012; Salvo et al., 2013; Broadway, 2017), in particular for rural areas (Spilková \& Fialová, 2013).

\section{Innovation and the reengineering of traditional spaces: an urban perspective}

According to the systematic review it is possible to attest that innovative processes applied to local food products and to traditional dishes are the focus of the urban perspective. Additionally, the reengineering of spaces in order to attract and fulfil the demand of food consumption places as arenas for experiencing other realities and socializing is also highlighted.

Montanari \& Staniscia (2009) argue that while in rural areas meaningful value is given to endogenous products, in urban areas creativity and innovation are more in vogue. An example is addressed by Hjalager \& Wahlberg (2014): they relate how science museum guests were invited to develop innovative local food through scientific experiments. Also Tresidder (2015) highlights how innovation, this time using creative cuisine technique on local products, 
serves to generate a creative gustatory experience in an urban context. In this innovative environment, the construct of authenticity is putted into question when stakeholders reinvent local traditions in order to fulfil touristic needs (Duruz, 2011).

As reviewed in the food clusters section, under a rural perspective, the terroir is a strategy to promote and preserve local identities. Nevertheless, in a rather controversial perspective, Broadway (2017, p. 468) affirms that "in the twenty-first century, the terroir's influence is minimal since food can literally be transported from anywhere to anywhere at any time of the year". It is the case of "wineproducing regions in the United States of America (USA) or New Zealand, which may lack an established viticultural heritage, yet they pursue the construction of some kind of 'placeness' in their marketing strategies" (Charters, 2010, cited in Gyimóthy, 2017, p. 1205). Another example is forwarded by Duruz (2011), who stresses on how "laksa", a Malaysian/Singaporean dish, became an Australian taste, questioning the sense of authenticity, emphasising how cross cultural encounters can add extra local identity.

When it comes to the reengineering of typical manufacturing places for tourism and production practices, the "in-betweeness" setting is a determinant factor for contemporary tourism demand. Actually, Everett (2012, p. 535) approaches in her research the issue of "global transformation of small food production sites into spaces of novel touristic experience". At the same time, she explores the interconnection between work places and tourism spaces underlining their dynamics when they are simultaneously acting as spaces of production and consumption. Everett (2012) found that increasing social and economic pressure have been put on producers to transform traditional productive spaces into touristic consumption places.

\section{Concluding remarks}

This systematic literature review revealed that food clusters and food-tourism networks are considered strategies in innovative territorial development (Boesen, Sundbo, \& Sundbo, 2017; Dougherty \& Green, 2011; Gyimóthy,
2017; James \& Halkier, 2014; Lee et al., 2016; Montanari \& Staniscia, 2009; Quaranta et al., 2016; Rinaldi, 2017).

Lee et al. (2015) described creative food clusters as organised food systems, yet they did not establish concrete connections to the creative economy, i.e., with creative areas/activities (performing arts, media, and architecture among others) and relationships (social, cultural and economic) among the different sectors.

When it comes to innovation, innovative attraction concepts are being developed within food tourism. Museums around local cuisines and/or their endogenous resources are highlighted (Hjalager \& Wahlberg, 2014). Additionally, traditional food production spaces are being reengineered into places of tourist consumption, which can provide more economic benefits for private stakeholders, but at the same time may provoke a commodification of immaterial heritage (e.g. local culinary know-how) into a "tourist friendly" use. The manipulation of traditional food processes in order to "facilitate growing consumptive demands and increase profits" (Everett, 2012, p. 551) may place the authenticity of traditions in question. Moreover, these changes in endogenous/typical processes can be seen as contradictory regarding the shift in consumer motivations who search for authentic experiences (IPK International, 2016).

The influence of territorial government policies (with the exception of marketing and branding strategies) is only emphasized by Lee et al. (2015). Their outcomes show that local community-based policies are not always financially supported by regional and national governments.

A dual approach to the phenomenon of food tourism is made by Montanari \& Staniscia (2009). Innovative and creative food is more likely to be demanded in urban areas rather than in rural environments in which authenticity and freshness of the products are the most relevant attributes. As a result, the rise of "signature cuisine" is an innovative approach to gastronomy and a way to overcome the lack of 
traditional foodways, as it happens in wine regions in USA, where place identities are created and "touristically" developed.

The systematic literature review showed that food clusters are viewed as an instrument to develop alternative food supply chains and, as a matter of fact, to achieve sustainable goals (Rinaldi, 2017). Sustainability is also addressed in the light of producers and production processes (Everett \& Aitchison, 2008) and, lastly, good food tourism practices and policies demonstrate their contribution to the local development of rural areas through, e.g., the creation of jobs in new food businesses, eventually linked to complementary services.

The present systematic review of literature on the role of food tourism in territorial innovation strategies, carried out as a part of an ongoing research project, has identified some unaddressed issues, which offer the opportunity for further research.

The majority of tourism-related firms (hospitality, food services, entertainment, among others) are micro-sized which reflects a fragmented industry. In this way, deepen studies exploring local food suppliers' network relationships with two different approaches are needed: one in which the focus should be on independent medium-sized restaurants inside hotel chains and a second approach, regarding micro-scale restaurants (particularly, those which are managed on a family basis).

Food tourism may have further indirect impacts on food exports. Nevertheless, to the best of the researchers' knowledge, there are few studies on how international tourists can become ambassadors of local products and how they can influence others, such as family and friends.

\section{Acknowledgments}

This research was supported by the project NORTE-01-0145-FEDER-000038 (INNOVINE \& WINE - Vineyard and Wine Innovation Platform) and by European and Structural and Investment Funds in the FEDER component, through the Operational Competitiveness and Internationalization Programme (COMPETE 2020) [Project No 006971 (UIC/SOC/04011)]; and national funds, through the FCT Portuguese Foundation for Science and Technology under the UID/SOC/04011/2013.

\section{References}

Alonso, A. D., Bressan, A., \& Sakellarios, N. (2017). Exploring innovation perceptions and practices among micro and small craft breweries: A three-country study. International Journal of Wine Business Research, 29 (2), 140-158.

Altinay, L., \& Paraskevas, A. (2008). Planning research in hospitality and tourism. London: Routledge Taylor \& Francis Group.

Boesen, Sundbo, \& Sundbo (2017). Local food and tourism: An entrepreneurial network approach. Scandinavian Journal of Hospitality and Tourism, 17 (1), 76-91.

Broadway, M. J. (2017). 'Putting Place on a Plate' along the West Cork Food Trail. Tourism Geographies, 19 (3), 467-482.

Burnett, K. (2014). Commodifying poverty: Gentrification and consumption in Vancouver's Downtown Eastside. Urban Geography, 35, 157-176.

Carlsen, J., \& Charters, S. (2006). Global wine tourism: Research, management and marketing. UK: CABI Publishing.

Carter, R. W. (Bill), Thok, S., O'Rourke, V., \& Pearce, T. (2015). Sustainable tourism and its use as a development strategy in Cambodia: A systematic literature review. Journal of Sustainable Tourism, 23 (5), 797-818.

Cavicchi, A., \& Stancova, K. C. (2016). Food and gastronomy as elements of regional innovation Strategies. Spain: European Commission. Joint Research Centre, Institute for Prospective Technological Studies.

Charters, S., \& Ali-Knight, J. (2001). Who is the wine tourist? Tourism Management, 23, 311-319.

Cooke, P. (2008). Regional innovation systems: Origin of the species. International Journal of Technological Learning, Innovation and Development, 1 (3), 393-409.

Dougherty, M. L., \& Green, G. P. (2011). Local food tourism networks and word of mouth. Journal of Extension, 49 (2), 1-8. 
Duruz, J. (2011). Tastes of hybrid belonging: Following the laksa trail in Katong, Singapore. Continuum, 25 (5), 605-618.

Elsevier. (2018a). Elsevier. URL: https://www. elsevier.com/solutions/scopus (Accessed on 02.01.2018).

Elsevier. (2018b). Scopus - Analyze search results. URL: https://www.elsevier.com/ solutions/scopus (Accessed on 17 November 2017).

European Commission. (2013). Agriculture and rural development, geographical indications and traditional specialities. URL: https://ec.europa.eu/agriculture/ quality/schemes/foodstuff_en (Accessed on 01.02.2016).

Eurostat. (2015). Expenditures on tourism trips. URL: http://ec.europa.eu/eurostat/data /database (Accessed on 22 November 2017).

Everett, S. (2012). Production places or consumption spaces? The place-making agency of food tourism in Ireland and Scotland. Tourism Geographies, 14 (4), 535-554.

Everett, S., \& Aitchison, C. (2008). The role of food tourism in sustaining regional identity: A case study of Cornwall, South West England. Journal of Sustainable Tourism, 16 (2), 150-167.

Fusté-Forné, F. (2016). Tasting cheesescapes in Cantebury (New Zealand). New Zealand Geographer, 72 (1), 41-50.

Getz, D. (2009). Policy for sustainable and responsible festivals and events: Institutionalization of a new paradigm. Journal of Policy Research in Tourism, Leisure and Events, 1 (1), 61-78.

Getz, D. (2000). Explore wine tourism: Management, development \& destinations. New York, NY: Cognizant Communication Cooperation.

Getz, D., Robinson, R., Andersson, T., \& Vujicic, S. (2014). Foodies \& food tourism. Oxford: Goodfellow Publishers, Ltd.

Gyimóthy, S. (2017). The reinvention of terroir in Danish food place promotion. European Planning Studies, 25 (7), 1200-1216.

Hall, C. M. (1996). Wine tourism in New Zealand. In G. Kearsley (eds.) (1996). Proceedings of Tourism Down Under II: A Tourism Research Conference, Centre for
Tourism. Dunedin: University of Otago, 109-119.

Hall, C. M., \& Mitchell, R. (2001). Special interest tourism: context and cases. In N. Douglas, N. Douglas \& R. Derrett (eds.) (2001). Special interest tourism: context and cases. Brisbane: John Wiley, 307329.

Hall, C. M., Sharples, L., Michell, R., Macionis, N., \& Cambourne, B. (2003). Food tourism around the world. Oxford: ButterworthHeinemann.

Hjalager, A. M. (2010). A review of innovation research in tourism. Tourism Management, 31 (1), 1-12.

Hjalager, A. M., \& Johansen, P. H. (2013). Food tourism in protected areas sustainability for producers, the environment and tourism? Journal of Sustainable Tourism, 21 (3), 417-433.

Hjalager, A. M., \& Richards, G. (2002). Tourism and Gastronomy. London: Routledge.

Hjalager, A. M., \& Wahlberg, M. (2014). Museum guests as contributors to regional food innovation. Museum Management and Curatorship, 29 (1), 50-65.

IPK International. (2016). ITB World Travel Trends Report December 2016. Berlin, Germany. URL: https://www.ttbberlin.de/media/itb/itb_dl_all/itb_presse_all World_Travel_Trends_Report_2016_201 7.pdf (Āccessed on 05.06.2017).

James, L., \& Halkier, H. (2014). Regional development platforms and related variety: Exploring the changing practices of food tourism in North Jutland, Denmark. European Urban and Regional Studies, 23 (4), 831-847.

Justiniano, M. N. H., Jaría-Chacón, N., \& VallsPasola, J. (2017). Innovation and experimental services: The role of multidisciplinary arts in creative gastronomy toward a research agenda. Direccion y Organizacion, 61, 32-47.

Kim, S., \& Ellis, A. (2015). Noodle production and consumption: From agriculture to food tourism in Japan. Tourism Geographies, 17 (1), 151-167.

Kiralova, A., \& Hamarneh, I. (2017). Local gastronomy as a prerequisite of food tourism development in the Czech Republic. Marketing and Management of Innovations, (2), 15-25. 
Kivela, J., \& Crotts, J. C. (2006). Tourism and gastronomy: Gastronomy's influence on how tourists experience a destination. Journal of Hospitality and Tourism Research, 30 (3), 354-377.

Kocaman, M., Kocaman, E.M. (2014). The importance of cultural and gastronomic tourism in local economic development: Zile sample. International Journal of Economics and Financial Issues, 4 (4), 735-744.

Lee, A. H. J., Wall, G., \& Kovacs, J. F. (2015). Creative food clusters and rural development through place branding: Culinary tourism initiatives in Stratford and Muskoka, Ontario, Canada. Journal of Rural Studies, 39, 133-144.

Lee, A. H. J., Wall, G., Kovacs, J. F., \& Kang, S. Y. (2016). Food clusters and creative tourism development: A conceptual framework. Journal of Rural and Community Development, 11 (2), 72-88.

Long, L. A. (1998). Culinary tourism. Lexington: The University Press of Kentucky.

Meethan, K. (1996). Consuming (in) the civilized city. Annals of Tourism Research, 23 (2), 322-340.

Metaxas, T., \& Karagiannis, D. (2016). Culinary tourism in Greece: Can the past define the future? Dimensions of innovation, entrepreneurship and regional development. Journal of Developmental Entrepreneurship, 21 (3), 1650018, 1-20.

Mitchell, R., \& Hall, C. M. (2003). Consuming tourists: Food tourism consumer behaviour. In Hall, C. M., Sharples, L., Mitchell, R., Macionis, N. \& Cambourne, B. (eds.) (2006). Food tourism around the world: Development, management and markets. (pp. 60-80). Oxford: ButterworthHeinemann.

Montanari, A., \& Staniscia, B. (2009). Culinary tourism as a tool for regional reequilibrium. European Planning Studies, 17 (10), 1463-1483.

Moulaert, F. \& Mehmood, A. (2010). Analysing regional development and policy: A structural-realist approach. Regional Studies, 44 (1), 103 - 118.

Moulaert, F. \& Sekia, F. (2003). Territorial innovation models: A critical survey. Regional Studies, 37 (3), 289 - 302.
Munadjat. (2016). Improving the welfare of small and medium enterprises of culinary tourism in the creative industries of Bandung City in the West. Man in India, 96 (8), 2439-2449.

OCTA \& Skift. (2015). The Rise of Food Tourism: Special Report. URL: https://ontarioculinary.com/the-rise-offood-tourism-trend-report/ (Accessed on 05.06.2017).

OECD. (2012). Food and Tourism Experience. The OECD Korea workshop, OECD Studies on Tourism. OECD Publishing. URL: http://www.oecd.org/cfe/tourism/food andthetourismexperiencetheoecd-korea workshop.htm (Accessed on 05.05.2017).

OECD. (2014). OECD Studies on Tourism: Tourism and the creative economy. OECD Publishing. URL: http://www.oecd. org/publications/tourism-and-the-creativeeconomy-9789264207875-en.htm (Accessed on 01.03.2017).

Perkins, H. C., Mackay, M., \& Espiner, S. (2015). Putting pinot alongside merino in Cromwell District, Central Otago, New Zealand: Rural amenity and the making of the global countryside. Journal of Rural Studies, 39, 85-98.

Petticrew, M., \& Roberts, H. (2006). Systematic reviews in the social sciences: a practical guide. Oxford: Blackwell Publishing.

Pickering, C., \& Byrne, J. (2014). The benefits of publishing systematic quantitative literature reviews for $\mathrm{PhD}$ candidates and other early-career researchers. Higher Education Research and Development, 33 (3), 534-548.

Prada-Trigo, J. (2017). Tourism, territory and cuisine: Food consideration and perceptions regarding origin and social changes: The case of Guinea pig. Journal of Tourism and Cultural Change, 6825 (August), 1-16.

Quaranta, G., Citro, E., \& Salvia, R. (2016). Economic and social sustainable synergies to promote innovations in rural tourism and local development. Sustainability (Switzerland), 8 (7), 1-15.

Richards, G. (2015). Evolving gastronomic experiences: From food to foodies to foodscapes. Journal of Gastronomy and Tourism, 1, 5-18. 
Richards, G. (2014). Património turismo e desenvolvimento regional. In Município de Arcos de Valdevez (eds.) (2014). Actas do $4 .^{\circ}$ Congresso Internacional Casa Nobre Um património para o futuro Arcos de Valdevez. Arcos de Valdevez: Município de Arcos de Valdevez, 1151-1159.

Richards, G. (2012). An overview of food and tourism trends and policies. In Dodd, D. (ed.) (2012). Food and the tourism experience. (pp. 13-46).Paris: OECD,

Rinaldi, C. (2017). Food and gastronomy for sustainable place development: A multidisciplinary analysis of different theoretical approaches. Sustainability (Switzerland), 9 (10), 1-25.

Salvo, P. De, Hernández-Mogollón, J. M., Di Clemente, E., \& Calzati, V. (2013). Territory, tourism and local products. The extra virgin oil's enhancement and promotion: A benchmarking Italy-Spain. Tourism and Hospitality Management, 19 (1), 23-34.

SClmago Journal \& Country Rank. (2018). Scimago Journal \& Country Rank URL: https://www.scimagojr.com/aboutus.php (Accessed on 02.02.2018).

Scott, A. J. (2010). The cultural economy of landscape and prospects for peripheral development in the twenty-first century: The case of the English Lake District. European Planning Studies, 18 (10), 1567-1589.

Sedarati, P., Santos, S., \& Pintassilgo, P. (2018). System dynamics in tourism planning and development. Tourism Planning \& Development, DOI: 10.1080/21568316.2018.1436586

Spilková, J., \& Fialová, D. (2013). Culinary tourism packages and regional brands in Czechia. Tourism Geographies, 15 (2), 177-197.

Stanley, J., \& Stanley, L. (2015). Food tourism: A practical marketing guide. UK: CABI Publishing.

Tresidder, R. (2015). Eating ants: understanding the terroir restaurant as a form of destination tourism. Journal of Tourism and Cultural Change, 13 (4), 344-360.
Tsai, C. T. (Simon). (2016). Memorable tourist experiences and place attachment when consuming local food. International Journal of Tourism Research, 18 (0), 536548.

UNCTAD. (2008). United Nations Conference on Trade and Development on the creative economy and industries for Chair's summary. Ghana. URL: http://unctad.org/en/Docs/td423_en.pdf (Accessed on 01.11.2016).

UNESCO-UIS. (2009). 2009 UNESCO Framework for cultural statistics. Quebec. URL:http://unesdoc.unesco.org /images/0019/001910/191061e.pdf (Accessed on 23.09.2017).

UNWTO. (2012). Global report on food tourism. Madrid, Spain. URL: http://cf.cdn.unwto. org/sites/all/files/docpdf/amreports4-food tourism.pdf (Accessed on 05.05.2017).

UNWTO. (2016). UNWTO Gastronomy Network action plan 2016/2017. URL: http://cf.cdn.unwto.org/sites/all/files/docpdf /gastronomyactionplanenweb.pdf (Accessed on 08.06.2017).

UNWTO. (2017). Second Global Report on Gastronomy Tourism - Affiliate Members Report: Volume sixteen. Madrid, Spain. URL: http://cf.cdn.unwto.org/sites/all/files /pdf/gastronomy_report_web.pdf (Accessed on 05.05.2017).

Web of Science - Clarivate. (2018). URL: https://clarivate.com/products/web-ofscience/ (Accessed on 02.01.2018).

Weed, M. (2006). Sports tourism research 2000-2004: A systematic review of knowledge and a meta-evaluation of methods. Journal of Sport and Tourism, 11 (1), 5-30.

WFTA. (2018). State of the food tourism industry 2018 Annual Report. URL: https://www.worldfoodtravel.org/articles/20 18-state-of-the-food-tourism-industryannual-report-released (Accessed on 20.04.2018).

Yeoman, I., McMahon-Beattie, U., Fields, K., Albrecht, J. N., \& Meethan, K. (2015). The future of food tourism. Bristol, UK: Channel View Publications. 